\title{
Suriyeli Sığınmacı Öğrencilerin Din Eğitimi Sorunları: Din Kültürü ve Ahlak Bilgisi Öğretmenleri Üzerine Nitel Bir Araştırma
}

\author{
Ali Baltacı ${ }^{1}$, Mehmet Kamil Coşkun² ${ }^{2}$, ìsa Ceylan ${ }^{3}$ (1)
}

Öz

Son yıllarda çeşitli nedenlerle artan göç hareketleri din eğitiminde de çeşitli sorunlara yol açmıştı. Bu araştırmanın amacı, Din Kültürü ve Ahlak Bilgisi (DKAB) dersi öğretmenlerinin görüşlerine göre Suriyeli sığınmacı öğrencilerin din eğitimi sorunlarının belirlenmesidir. Ayrıca araştrma kapsamında ilgili sorunlara ilişkin öğretmenlerce önerilen olası çözüm yöntemlerine de yer verilmiştir. Araştırma, nitel araştırma yöntemlerinden durum çalışması modeli ile tasarlanmıştr. Araştırma verileri amaçlı nitel araştırma örneklem yöntemlerinden olan maksimum çeşitlilik örneklem yöntemi ile İstanbul ilinin Küçükçekmece, Bağcılar, Sultangazi, Fatih ve Esenyurt ilçelerinde 45 okulda çalışan 79 DKAB öğretmeninden toplanmıştır. Araştırma sonucunda, Suriyeli sı̆̆ınmacı öğrencilerin genel olarak bilişsel, duyuşsal, davranışsal, gelişimsel ve sosyal sorunları olduğu belirlenmiştir. Din derslerinde yaşanan en önemli sorun dil ve sınıf içi disiplin sorunları ile din derslerine karşı sergilenen olumsuz tavırlardır. Ayrıca din öğretimi müfredatt ile ilgili sorunlar da bulunmaktadır. Öğretmenlere göre öğrencilere dil ve uyum eğitimi verilmesi ile okullarda yaşanan pek çok sorun çözümlenebilir.

\author{
Anahtar Kelimeler \\ Din eğitimi, Suriyeli sığınmacı öğrenciler, Öğretmen, Öğrenci, Sorun
}

The Problems of Religious Education of Syrian Asylum Seeker Students: A Qualitative Study on Religious Education Teachers

\begin{abstract}
In recent years, the increasing migration movements caused various problems in religious education. The aim of this study is to determine the problems of religious education of Syrian refugee students according to religious education teachers. In addition, possible solution methods proposed by the teachers regarding the related problems were also included in the research. The research is designed with the case study method of qualitative research methods. The research data were collected from 79 teachers working in 45 schools in the Küçükçekmece, Bağcılar, Sultangazi, Fatih and Esenyurt districts of İstanbul province, with the maximum diversity sampling method, which is one of the qualitative research sampling methods. As a result of the research, it has been determined that Syrian refugee students generally have cognitive, affective, behavioral, developmental and social problems. The most important problems experienced in the religion courses are language and classroom discipline problems, and negative attitudes against religion courses. There are also problems with the religious education curriculum. According to the teachers, many problems in schools can be solved by offering language and adaptation training to students.
\end{abstract}

\section{Keywords}

Religious education, Syrian refugee students, Teacher, Student, Problem

1 Sorumlu Yazar: Ali Baltacı (Dr. Öğr. Üyesi), Mersin Üniversitesi, İslami İlimler Fakültesi, Felsefe ve Din Bilimleri Bölümü, Mersin, Türkiye. E-posta: alibaltaci@mersin.edu.tr ORCID: 0000-0003-2550-8698

2 Mehmet Kamil Coşkun (Doç. Dr.), Ankara Hacı Bayram Veli Üniversitesi, Polatı Ilahiyat Fakültesi, Din Eğitimi Anabilim Dalı, Ankara, Türkiye. E-posta: kamil.coskun@hbv.edu.tr ORCID: 0000-0002-5669-2777

3 İsa Ceylan (Dr. Arş. Gör.), Ankara Üniversitesi, İlahiyat Fakültesi, Din Psikolojisi Anabilim Dalı, Ankara, Türkiye.

E-posta: isa.ceylan@ankara.edu.tr ORCID: 0000-0002-6163-5689

Atrf: Baltaci, Ali, Coskun, Mehmet-Kamil ve Ceylan, Isa. "Suriyeli Sığınmacı Öğrencilerin Din Eğitimi Sorunları: Din Kültürü ve Ahlak Bilgisi Öğretmenleri Üzerine Nitel Bir Araştirma." darulfunun ilahiyat 30, 2 (2019): 383-405. https://doi.org/10.26650/di.2019.30.2.0018 


\section{Extended Summary}

Due to the ongoing civil war in Syria, there is an intense migratory flow towards Turkey. Increased asylum seekers can lead to problems of a different kind in Turkey's social, cultural and economic life. One of the important problems arising from the migration movement is education. There are various problems that they encounter in the religious education of Syrian asylum seekers living in Turkey. That the majority of Syrian asylum seekers, because of Muslim beliefs, and for that, they can easily adapt to the offered religious education in Turkey is the main motive in the conduct of this study. At this point, we see the necessity of obtaining the opinions of religious education (RE) teachers about the religious education offered to these students, which encountered the Syrian students in their practice. It is possible to improve the quality of religious education provided to Syrian students by understanding the problems experienced by the teachers. In this study, RE teachers' problems faced by Syrian students in religious education, obstacles to religious education and teachers' suggestions for solving the problems were investigated. In this study, current data on the problems of religious education are presented to religious academics and policymakers. Within the scope of this study, answers to the following questions were sought.

1) What are the problems faced in the general education of Syrian students and in religious education?

2) What are the obstacles to the quality of religious education in schools and classrooms?

3) What are the regulations for the religious education of Syrian students?

4) What recommendations do RE teachers have for the religious education of Syrian students?

This study was conducted with a case study design, which is one of the qualitative research methods. The research was conducted with RE teachers who participated in Syrian refugee students' classes, and it was decided to use the maximum diversity sample from the qualitative research sampling methods because of the attendance of these students to schools in certain regions. This study was conducted in a total of 45 primary schools, including 15 primary schools and 17 imam-hatip schools, in districts of Istanbul province (Küçükçekmece, Bağcılar, Sultangazi, Fatih, and Esenyurt). In order to increase the diversity of the study group, all RE teachers in these schools who volunteered to participate in the study were included in the sample group. The sample group consisted of $79 \mathrm{RE}$ teachers, of which 38 were female and 41 were male. It was decided to conduct an interview to collect the data and a semi-structured interview form was prepared for the interviews with teachers. The content analysis method, one of the qualitative data analysis methods, was used in the study. 
According to RE teachers, Syrian students experience cognitive, affective, behavioral, developmental and social problems in schools. Problems such as difficulty in perception, retardation in verbal skills, anxious mood, distractions, a tendency to violence and inability to make friends are common among Syrian students. Moreover, these students experience social and cultural adaptation problems. The majority of the teachers reported that they did not do any special work for Syrians in religious education. Some of the teachers reported that they did additional studies outside the class by using Arabic religious education books. In addition, few teachers stated that they hung posters and images about religious education in class. However, a limited number of teachers stated that they distributed the Arabic religious stories to the students in accordance with the language and academic levels of the Syrian students. The majority of the teachers think that the curriculum of religious education is appropriate for Turkish students but not for Syrian students. According to the teachers, there should be an alternative curriculum of religious instruction focusing on the problem of cultural and social adaptation of the Syrian students. In addition, teachers' opinions regarding the necessity of preparing a new curriculum for religious education in accordance with the universal Islamic values and considering the spiritual needs of Syrians are important.

RE teachers think that the fact that Syrian students do not speak Turkish is an important educational barrier. Moreover, their inability to speak Arabic is seen as an important deficiency. According to RE teachers, sectarian differences, student absenteeism, irrelevant parents and the effects of secular life adversely affect the religious education of Syrian students. According to some teachers, Syrian students behave undisciplined, sabotage the teacher and bully their friends. Prejudiced attitudes and behaviors of Turkish students towards Syrians are also an important educational barrier. All RE teachers reported that Syrians had a negative attitude towards religious classes and were indifferent to the classes. All RE teachers suggested that Syrian parents and students should be given Turkish, literacy, cultural and social cohesion education, and that the curriculum of religious education should be renewed. In addition, teachers recommended that parents and students receive spiritual counseling, empathy training to reduce prejudices and work to solve the problem of absenteeism. 


\section{Giriş}

Tarihsel süreçte doğal afetler veya savaşlar gibi çok çeşitli nedenlerle insanlar farklı coğrafyalar arasında yer değiştirmiş; bu dinamik süreç güncel bir olgu olarak günümüzde de devam etmektedir. Suriye'deki iç savaş nedeniyle Ürdün, Lübnan ve Türkiye gibi çevre ülkelere kitlesel insan hareketi sürmekte ve bu durum sosyal, kültürel ve ekonomik düzeyde farklı sorunları tetiklemektedir. Göç hareketi sonucunda oluşan önemli sorunlardan biri de eğitimdir. Yer değiştirenlerin nasıl ve nerede eğitilecekleri veya hangi eğitsel değerlerle bezenmiş bir öğretim müfredatının ne şekilde uygulanacağı gibi tartışmalar güncelliğini korumaktadır. Bununla birlikte Türkiye'de yaşayan Suriyeli sığınmacıların din eğitiminde karşılaştıkları çeşitli sorunlar bulunmaktadır. Suriyeli sığınmacıların çoğunluğunun Müslüman olması hasebi ile Türkiye'de sunulan din eğitimine kolay uyum sağlayabileceklerine yönelik inançlar, bu araştırmanın yürütülmesindeki temel güdüdür. Bu noktada Suriyeli sığınmacılarla pratik olarak temas eden Din Kültürü ve Ahlak Bilgisi (DKAB) dersi öğretmenlerinin, bu öğrencilere sunulan din eğitimi hakkındaki görüşlerinin alınması gerekliliği oluşmuştur. DKAB öğretmenlerinin yaşadığı sorunların anlaşılması ile Suriyeli sığınmacılara sağlanan din eğitiminin kalitesinin arttırılması olasıdır. Ayrıca DKAB öğretmenlerinin, sınıf içi din eğitimi uygulamalarının ve sığınmacı çocukların eğitimi konusunda ne düzeyde bilinçli olduklarının belirlenmesi önemlidir. Eğitim çağındaki Suriyeli sığınmacıların büyük bir kısmının din eğitimine erişimlerinin sınırlı olduğu düşünüldüğünde, gelecekte bu çocukların toplum içinde oluşturabilecekleri istenmeyen durumlar daha iyi anlaşılabilir. Bu açıdan Suriyeli sığınmacı öğrencilerin din eğitimi ihtiyaçlarının ne düzeyde karşılandığı, din eğitimi ihtiyaçlarının neler olduğu, din eğitimi için ihtiyaç duydukları öğretmen, ortam ve müfredatın ne derece kaliteli olduğu sorunsalının görünür kılınması, var olan din eğitimi tartışmalarına yeni bir yönelim açılması adına önemlidir. Ayrıca çalışma ile din eğitimi politika belirleyicileri için din eğitiminin sorunlarını gündeme taşıyan bir veri ortamı sunulacak ve sığınmacı öğrencilerin aldıkları din eğitiminin kalitesini arttıracak yeni uygulamalar için zemin hazırlanacaktır. Bu noktadan hareketle bu çalışma kapsamında, "(1) Suriyeli sığınmacı öğrencilerin genel eğitimleri ile din eğitiminde karşılaşılan sorunlar nelerdir? (2) Okul ve sinıflarda sürdürülen din eğitiminin kalitesine engel durumlar nelerdir? (3) Sığınmacı öğrencilerin din eğitimine yönelik düzenlemeler nelerdir? (4) DKAB öğretmenlerinin Sığınmacı öğrencilerin din eğitimine yönelik ne gibi önerileri vardır?" sorularına yanıt aranmaya çalışılacaktır. Bu kapsamda ilerleyen bölümde din eğitimi ve Suriyeli sığınmacılar konusu tartışılmış, daha sonra konu bağlamına uygun şekilde sunulmaya çalışılmıştır. 


\section{Türkiye'deki Suriyeli Sığınmacılar ve Din Eğitimi}

Suriye'de yıllar süren iç savaştan kaçanların en fazla sığındığı ülke olan Türkiye, 2019 yılı resmi rakamlarına göre 3,6 milyonun üzerinde sığınmacıya ev sahipliği yapmaktadır. ' Suriyelilerin bu denli yoğun bir şekilde göç etmesi sonucu Türkiye'de ekonomik, sosyal, siyasal, kültürel, eğitim ve sağlık sorunları yaşanmakta; ülkenin var olan sorunlarına yeni ve muhtemelen kronikleşecek sorunlar eklenmektedir. ${ }^{2}$ Ülkeye giriş yaptıkları 2010 ve 2011 yıllarında geçici misafir olarak değerlendirilen Suriyeliler, zamanla geçici korunma altındaki sığınmacılar veya kısaca sığınmacı olarak adlandırılmış ${ }^{3}$ ve toplumsal düzene uyum sağlamalarına uyuma yönelik herhangi bir politika belirlenmemiştir; kamu kurumlarında geri dönmeyeceklerine yönelik bir algı oluştuktan sonra Suriyelilerle ilgili kalıcı politikalar üretilmeye başlanmıştır. ${ }^{4}$

Eğitim sistemi içindeki Suriyeli sığınmacılar için ilk yıllarda herhangi bir eğitim politikası belirlenmezken, 2013 yılından itibaren sığınmacılara yönelik yasal düzenlemelerin gerekliği tartışılmaya başlanmıştır. 2014 yılında 6458 sayılı "Yabancılar ve Uluslararası Koruma Kanunu" yürürlüğe girmiş; sığınmacı çocukların eğitiminde izlenecek yollar, çocuklara yönelik eğitim programlarının hazırlanması, çocuklara eğitim verecek öğretmenlerin nitelikleri ve öğretmen ile diğer ihtiyaçların nasıl karşılanacağına ilişkin bilgilere bu kanunda yer verilmiştir. ${ }^{5} \mathrm{Bu}$ dönemden sonra çeşitli yönetmelik ve yönergeler ile kanunun açıklanması ve uygulanması sağlanmış olsa da eğitim sistemi içinde 1 milyondan fazla Suriyeli sığınmacının olduğu düşünüldüğünde, kanun kapsamında yer almayan veya sonradan beliren çeşitli sorunların eğitim sistemini zorladığı söylenebilir. ${ }^{6}$ Bu sorunlardan biri sığınmacılara sunulacak eğitim hizmetinin nerede verileceğidir. Başlangıçta Suriyeli öğrencilerin

1 “Türkiye'deki Suriyeli Sayısı Nisan 2019 - Mülteciler Derneği”, erişim: 29 Nisan 2019, https:// multeciler.org.tr/turkiyedeki-suriyeli-sayisi/.

2 Ibrahim Sirkeci, "Turkey's refugees, Syrians and refugees from Turkey: a country of insecurity", Migration Letters 14, sy 1 (2017): 129.

3 Tuba Bircan, "Educational assessment of Syrian refugees in Turkey", Migration Letters 12, sy 3 (2015): 228.

4 Derya Kap, "Suriyeli mülteciler: Türkiye'nin müstakbel vatandaşları”, Akademik Perspektif 1 , sy 3 (2014): 30-35; Zeki Boyraz, “Türkiye'de göçmen sorununa örnek Suriyeli mülteciler”, Zeitschrift für die Welt der Türken/Journal of World of Turks 7, sy 2 (2015): 35-58; Suna Gülfer Ihlamur-Öner, “Türkiye'nin Suriyeli mültecilere yönelik politikası”, Ortadoğu Analiz 6, sy 61 (2014): 42-45.

5 Ali Rıza Seydi, “Türkiye'nin Suriyeli sığınmacıların eğitim sorununun çözümüne yönelik izlediği politikalar”, Süleyman Demirel Üniversitesi Fen-Edebiyat Fakültesi Sosyal Bilimler Dergisi 2014, sy 31 (2014); Müberra Nur Emin, “Türkiye'deki Suriyeli çocukların eğitimi: Temel eğitim politikaları” (Seta, 2016).

6 Emin, “Türkiye'deki Suriyeli çocukların eğitimi: Temel eğitim politikaları”, 41; Özkan Yıldız, "Türkiye Kamplarında Suriyeli Sığınmacılar: Sorunlar, Beklentiler, Türkiye ve Gelecek Algısı", Sosyoloji Araştırmaları Dergisi 16, sy 1 (2013): 148. 
eğitime devam edebilecekleri yerler olarak kamplardaki Geçici Eğitim Merkezleri (GEM) ve diğer eğitim kurumları gösterilmiş olup; Suriyelilere devlet okullarına kayıt olma hakkı verilmemiştir. Ancak 23 Eylül 2014 tarihli "Yabancılara Yönelik Eğitim-Öğretim Hizmetleri” başl1klı, genelge ile Suriyeli öğrencilerin yalnızca GEM'lere değil devlet okullarına da kayıt olma hakkı kazandıkları belirlenebilir. $\mathrm{Bu}$ genelge, Suriyeli çocuklara sunulacak eğitim hizmetlerinin belirli bir standarda bağlanmasını güvence altına alması bakımından önemlidir. ${ }^{7}$ Buna karşın sığınma kamplarının kapatılması ve sığınmacıların şehirlere yönlendirilmesi ile Suriyeli sığınmacıların, Türk eğitim sistemi içine dâhil edilmeye başlandığı ve eğitim sistemindeki söz konusu ikiliğin ortadan kaldırıldığı bilinmektedir. ${ }^{8}$

Din eğitimi, çocuğun toplumsal düzene uyumunu kolaylaştıran; geleneksel ile modern toplumsal düzen arasında köprü işlevi gören önemli bir disiplindir. ${ }^{9}$ Sığınmacı öğrencilerle çalışan öğretmenler farklı eğitsel sorunlar yaşamakla birlikte, din eğitimi bu sorun alanlarından birisi olması sebebiyle önem taşır. Öncelikle Suriyeli sığınmacıların çoğunluğu Müslüman olması sebebiyle belirli düzeyde din bilgisine sahiptir. Ayrıca özellikle GEM'lerde Suriye'deki din öğretim programının sürdürüldüğü; buna karşın devlet okullarında Türk din öğretim programının uygulandığı bilinmektedir. Din öğretimindeki söz konusu iki başlılık ileride belirgin sorunları beraberinde getirebilir. Öncelikle Türkiye'deki din öğretimi programının dinler üstü bir anlayışta olduğu; buna karşın Suriye'de din/mezhep temelli bir öğretimin olması, iki program arasındaki ön önemli farklılıktır. Ayrıca kültürlerarası ve çoğulcu bir yaklaşımla yazılan Türk din öğretimi müfredatına karşın Suriye din öğretimi müfredatı tek yönlü bir yapı arz eder. Son olarak sarmal ve yapılandırıcı yaklaşımın etkin olduğu Türk din öğretiminin aksine Suriye'de geleneksel din eğitim anlayışına dayalı bir yaklaşım söz konusudur. Din öğretimindeki bu ayrıklaşma, Suriyelilerin eğitim gördüğü okullarda belirgin din eğitimi sorunlarına yol açmaktadır. ${ }^{10}$

7 Ömür Kızıl ve Cengiz Dönmez, “Türkiye'deki Suriyeli Sığınmacılara Sağlanan Eğitim Hizmetleri ve Sosyal Bilgiler Eğitimi Bağlamında Bazı Sorunların Değerlendirilmesi”, International Journal of Education Technology and Scientific Researches 2, sy 4 (2017): 214.

8 Fırat Fıstık, "Suriyelilerin kaldığı çadır kentler kapatılıyor, gelecekleri belirsiz", Medyascope, 22 Mayıs 2019, https://medyascope.tv/2019/05/22/suriyelilerin-kaldigi-cadir-kentler-kapatiliyorgelecekleri-belirsiz/.

9 Beyza Bilgin, Türkiye'de din eğitimi ve liselerde din dersleri (Emel Matbaacılık, 1980); Recai Doğan - Nurullah Altaş, "Din Öğretiminde Yeni Yöntem Tartışmalarında Kuramdan Uygulamaya: İlköğretim Din Kültürü ve Ahlak Bilgisi Programları (Ankara Modeli)”, Değerler Eğitimi Dergisi 2/5 (2004): 23-38.

10 Monique C. Cardinal, "Religious education in Syria: unity and difference", British Journal of religious education 31, sy 2 (2009): 91-101; Joshua Landis, "Islamic education in Syria: Undoing secularism", Teaching Islam: Textbooks and Religion in the Middle East, 2003, 177-196. 
Özellikle ortaokul ve lise dönemindeki sığınmacı öğrencilerin \%63’ünün, gerek Arapçanın daha sık kullanılması gerekse dini ve kültürel değerlere dayalı din öğretimi yapılması gibi gerekçelerle İmam-Hatip okullarını tercih ettikleri bilinmektedir. ${ }^{11}$ Eğitimin nicel artışından ziyade niceliğin, niteliği desteklediği ölçüde önemli olduğu düşüncesinden hareketle, topluma etkili bir din eğitimi sağlanabilmesi için DKAB öğretmenlerinin okullarda sundukları din eğitiminin kalitesine ilişkin görüşlerinin dikkate alınması gerekliği önem arz etmektedir. Türk öğrenciler için hazırlanan din öğretimi programı bulunsa da sığınmacı öğrencilerin din öğretimine yönelik plan ve programların hazırlanmamış olması önemli bir eksikliktir. Bu açıdan sığınmacı öğrencilerle çalışan DKAB öğretmenleri birçok güçlükle karşılaşmakta ve genellikle gündelik çözümler ile bu öğrencilere din eğitimi sunmaktadırlar.

Din eğitimi, kişinin geçmiş yaşantılarında edindiği dini ve ahlaki bilgiler ile toplumsal değerlerden etkilenir. ${ }^{12} \mathrm{Bu}$ açıdan $\mathrm{DKAB}$ öğretmenlerinin, öğrencinin geçmiş öğrenmelerini bilmesi önemlidir. Oysa sığınmacıların eğitim geçmişleri ve din eğitimine yönelik kazanımlarının bilinmesi oldukça zordur. DKAB öğretmeninin sınıflarda sığınmacılara yönelik nasıl bir din eğitimi sunması gerektiği ya da sığınmacı öğrencinin geçmiş deneyimleriyle edindiği dini bilgi, değer ve kültürün gerek öğretmeni gerekse diğer öğrencileri nasıl etkileyeceğinin bilinmesi, okullarda sunulan din eğitiminin kalitesinin arttırılması açısından önemlidir.

Din eğitimi, toplumsal gerginlikleri azaltmada veya toplumun önyargılarını kırmada etkilidir. ${ }^{13}$ Din eğitimi müfredatı içerisinde öğrenciye aktarılması hedeflenen kök değerler: adalet, dostluk, dürüstlük, öz denetim, sabır, saygı, sevgi, sorumluluk, vatanseverlik ve yardımseverlik olarak belirlenmiştir. ${ }^{14}$ Suriyeli sığınmacılara karşı toplum içinde geliştirilen olumsuz duygu durumunun azaltılması, toplumun değerlerinin sığınmacılar tarafından kabul edilmesi ve sığınmacıların da potansiyel tehlikelere karşı korunması ile mümkün olabilir. Okullarda öğretmenler tüm öğrencilerin davranışları üzerinde etkili değişimler oluşturabilir. Ancak sorumluluk

11 Shelly Culbertson ve Louay Constant, Education of Syrian refugee children: Managing the crisis in Turkey, Lebanon, and Jordan (Rand Corporation, 2015), 22-24; İhsan Dörtkardeş, "Suriyeli öğrenciler imam hatiplere yönlendirilsin' genelgesi - Son Dakika Flaş Haberler", erişim: 26.05.2019, https://www.cnnturk.com/turkiye/suriyeli-ogrenciler-imam-hatiplere-yonlendirilsingenelgesi; Ömer Fethi Gürer, "36 bin 385 Suriyeli İmam hatip okullarında eğitim görüyor”, BirGün Gazetesi, 2018, erişim: 26.05.2019, https://www.birgun.net/haber-detay/36-bin-385suriyeli-imam-hatip-okullarinda-egitim-goruyor-209499.html.

12 Cemal Tosun, Din ve kimlik, c. 118 (Türkiye Diyanet Vakfı, 1993).

13 Nurullah Altaş, Gençlik döneminde din olgusu ve liselerde din öğretimi (Nobel, 2004).

14 Ali Baltacı, "Din kültürü ve ahlak bilgisi öğretmenlerinin örgütsel adalet algısı ve iş doyum düzeyleri arasındaki ilişki”, İnönü Üniversitesi Eğitim Bilimleri Enstitüsü Dergisi 6, sy 11 (2019): 28-49. 
alanı itibarıyla öğrencilere ahlaki değer ve yaşantıları kazandırma görevini üstlenen DKAB öğretmenlerine özel bir yük düşmektedir. DKAB öğretmenleri, Suriyeli sığınmacılar ile Türk öğrenciler arasındaki ortak noktalardan biri olan İslam'ın değer ve ilkelerini kullanarak bu iki farklı kültürü birleştirebilirler. Okul içinde yaşanan sosyal gerginliklerin azaltılmasında din eğitiminin etkisinin arttırılması ile gruplar arası empati sağlanırken, önyargı ve dışlanma durumları azaltılabilir. $\mathrm{Bu}$ açıdan DKAB öğretmenleri din eğitiminin çeşitli yaklaşımlarını kullanarak gerek sığınmacılarla gerek Türk öğrencilerle dinamik ve iyi ilişkiler oluşturabilir; bu yolla öğrencilerin birbirleri hakkındaki bilişsel, sosyal ve duygusal önyargı ve gerginliklerini azaltabilir. ${ }^{15}$

Eğitim sistemi içinde gerek imam-hatiplerde gerekse diğer okullarda sunulan din eğitiminin kalitesindeki dalgalanmalar akıllara toplumsal uyumun, din eğitimi ile nasıl çözümleneceği sorusunu getirmektedir. Toplumsal uyum sorunları, sığınmacıların eğitimine engel teşkil eden önemli bir olgudur. Tarihsel olarak göçebe yaşayan Türk toplumları gittikleri bölgelere kolay uyum sağlamışlar, toplumun bir parçası olmayı başarabilmişlerdir. Buna karşın Ortadoğu halklarının kendi kültürlerini koruma isteği ve kemikleşmiş değer yargıları nedeniyle misafir oldukları ülkelerin toplumlarına uyma isteksizlikleri bilinmektedir. ${ }^{16}$ Din eğitiminin toplumları kaynaştırıcı doğası kullanılarak ortak bir din üzerinden sağlanabilecek uzlaşmayla sığınmacıların topluma adapte olmaları sağlanabilir. Bu durum bireysel olarak DKAB öğretmenlerinin sorumluluk alanını aşarak bir devlet politikasını gerektirmektedir. Suriyeli sığınmacıları imam-hatip okullarına yönlendiren erkin, bu gibi genel politikaları belirlemesi elzemdir.

\section{Yöntem}

\section{Araştırma Deseni}

$\mathrm{Bu}$ araştırma "DKAB öğretmenlerinin görüşlerine göre Suriyeli sığınmacı öğrencilerin din eğitimine ilişkin sorunları nelerdir?” sorusuna cevap aramak için nitel araştırma yöntemlerinden olan durum çalışması deseniyle yürütülmüştür.

15 Yusuf Batar, Empatik din eğitimi (Elips Kitap, 2011); Nevzat Aşıkoğlu, "Din öğretiminde öğretmenin rolü ve din dersi öğretmeni yeterlilikleri (Türkiye örneği)", Cumhuriyet Üniversitesi Illahiyat Fakültesi Dergisi 15, sy 1 (2011): 5-13; Yıldız Kızılabdullah ve Tuğrul Yürük, "Din eğitimi modelleri çerçevesinde Türkiye'deki din eğitimi üzerine genel bir değerlendirme”, Dini Araştırmalar 11, sy 32 (2008): 107-130.

16 Betul Dilara Şeker, Ibrahim Sirkeci, ve M. Murat Yüceşahin, Göç ve uyum (Transnational Press London, 2015); Betül Duman, "Yoğun göç almış metropollerde etniklik ve öteki ile ilişki”, Sosyoloji Dergisi 3, sy 27 (2013): 1-24; Suat Kolukırık, "Uluslararası göç ve Türkiye: Yerel uygulamalar ve görünümler”, Zeitschrift für die Welt der Türken/Journal of World of Turks 6, sy 2 (2014): 37-53. 
Nitel araştırmalar olay ve olguların nedenleri, oluş biçimleri ve etkileri hakkında detaylı incelemeleri olanak tanımaktadır. ${ }^{17}$ Durum çalışması ise araştırmacının bir veya birkaç sorunu ayrıntılı olarak incelemesine imkân tanıyan olay ve olgulara odaklanması, durumlara bağlı temaları açığa çıkarmasını kolaylaştıran nitel araştırma desenidir. ${ }^{18} \mathrm{Bu}$ araştırmada, DKAB öğretmenlerinin, Suriyeli sığınmacı öğrencilerin din eğitimine yönelik yaşadıkları sorunlar ile din eğitimine engel olabilen durumları ve öğretmenlerin söz konusu sorunların çözümü için neler önerdiğini detaylı inceleyebilmek amacıyla durum çalışması kullanılmıştır.

\section{Çalışma Grubu}

Araştırma, Suriyeli sığınmacı öğrencilerin dersine giren DKAB öğretmenleriyle yapıldığı ve bu öğrencilerin belirli bölgelerdeki okullara devam etmesi nedeniyle amaçlı nitel araştırma örneklem yöntemlerinden maksimum çeşitlilik örnekleminin kullanılmasına karar verilmiştir. Bu yöntem farklı ve çeşitli durumların incelenmesine olanak sağlayan ve verilerin derinliklerinin daha kolay algılanmasını sağlayan örnekleme yöntemidir. ${ }^{19} \mathrm{Bu}$ amaçla İstanbul İli, Küçükçekmece, Bağcılar, Sultangazi, Fatih ve Esenyurt ilçelerinde Suriyeli çocukların çoğunlukla devam ettiği 13 ilkokul ile 15 ortaokul ve 17 imam-hatip ortaokulu olmak üzere toplam 45 okulda araştırma yürütülmüş̧ür. Çalışma grubunun çeşitliliğini arttırmak amacıyla bu okullardaki tüm DKAB öğretmenlerinden çalışmaya gönüllü olarak katılmak isteyenler örneklem grubuna alınmıştır. Çalışma grubu 79 DKAB öğretmeninden oluşmakta olup bu öğretmenlerin 38'i kadın 41'i erkektir. Veri toplanan 33 öğretmen, 1-5 yıl arası, 29 öğretmen 5-15 yıl aras1, 17 öğretmen ise 15 y1l ve üzeri mesleki kıdeme sahiptir. Öğretmenlerden 59'u DKAB lisans mezunu iken 20'si İlahiyat Fakültesi mezunudur. Ayrıca 15 öğretmen alanında yüksek lisans eğitimi almıştır.

\section{Verilerin Toplanması}

DKAB öğretmenleriyle yapılan mülakatlar için yarı-yapılandırılmış mülakat formu hazırlanmıştır. İlgili literatür incelenerek mülakat formunda yer alması uygun olan sorular hazırlanmış, hazırlanan taslak form 3 din eğitimi, 2 program geliştirme, 2 ölçme ve değerlendirme, 2 Türk dili ile 2 psikolojik danışmandan oluşan bir uzman grubunun görüşleri alınarak geliştirilmiştir. Mülakat formunun

17 Ali Baltac1, "Nitel veri analizinde Miles-Huberman modeli", Ahi Evran Üniversitesi Sosyal Bilimler Enstitüsü Dergisi 3, sy 1 (2017): 1-15.

18 John W. Creswell, Educational research: Planning, conducting, and evaluating quantitative (Prentice Hall Upper Saddle River, NJ, 2002).

19 Ali Baltacı, "Nitel araştırmalarda örnekleme yöntemleri ve örnek hacmi sorunsalı üzerine kavramsal bir inceleme", Bitlis Eren Üniversitesi Sosyal Bilimler Enstitüsü Dergisi 7, sy 1 (2018): 231-274. 
ön uygulaması İstanbul ili Zeytinburnu İlçesinde Suriyeli sığınmacı öğrencilerin bulunduğu bir ortaokuldaki $3 \mathrm{DKAB}$ öğretmenine uygulanmış ve formun belirlemek istediği görüşleri ayrıştırabilecek sorular içerdiği, yani geçerliğinin bulunduğuna karar verilmiştir. Mülakat formunda yer alan sorulardan bazıları: (1) Suriyeli sığınmacı öğrencilerde sık görülen din eğitimi sorunları nelerdir? (2) Suriyeli sığınmacı öğrencilere din eğitimi vermenizde engel oluşturduğunu düşündüğünüz durumlar var mıdır? Eğer var ise örnek verir misiniz? (3) Sizce din öğretimi müfredatı Suriyeli sığınmacı öğrencilerin din eğitimleri için yeterli midir? şeklinde örneklendirilebilir.

DKAB öğretmenlerinin mülakat formunda yer alan sorulara verdikleri cevaplar ses kaydedici ile kayıt altına alınmış; ayrıca araştırmacılar ses kayıtlarında yer almayan önemli durumların varlığını belirlemek için sahada bazı notlar da almıştır. Yüz yüze görüşmelerle gerçekleştirilen ve 79 öğretmenden toplanan 143 saat 18 dakikalık ses kayıtları ile 54 sayfalık veri notları, bu çalışmanın veri setini oluşturmaktadır. Örneklemdeki tüm DKAB öğretmenlerine aynı sorular sorulmuş; araştırmacılar öğretmenlere "çoklu ve yönlendirici sorular" ile cevabı "evet veya hayır" olabilecek sorular sormaktan kaçınmıştır. Yarı yapılandırılmış mülakatlar, gerekli yasal izinler alındıktan sonra, okullarda mülakatlar için özel olarak hazırlanan yönetici veya rehberlik servisi odası veya okul kütüphanesinde gerçekleştirilmiştir. Araştırmanın iç geçerliliği literatürdeki benzer araştırma soruları ile karşılaştırılarak, dış geçerliliği ise alan uzmanlarının görüşleri doğrultusunda sağlanmıştır.

\section{Verilerin Analizi}

Araştırmada nitel veri analiz yöntemlerinden içerik analizi yöntemi kullanılmış; bu amaçla Miles ve Huberman (1994) tarafından önerilen tümevarımsal kodlamakategorileştirme ve temalara ayırma tekniğinden yararlanılmıştır. ${ }^{20}$ Araştırmada kullanılan veri seti (yazılı ve sözlü materyaller) sistemli ve ayrıntılı bir temizleme işleme ile ayrıştırılmış ve bu aşamada ilk kodlara ulaşıııışır. Daha sonra kodlar bir araya getirilerek temel kavramsal yapı ortaya çıkarılmış, kavramların birleştirilmesi ile kategoriler belirginleşmiştir. Farklı kategoriler bir araya getirilip temalar oluşturulmuş ve tümevarım yöntemi ile araştırma kapsamında incelenen olay ve olguya ilişkin bütüncül bir imge yaratılmıştır. Veriler araştırmacılar tarafından ayrı ayrı kodlanmış, ayrıca kodlayıcı güvenirliğini sağlamak için nitel veri analizinde uzman 3 farklı kodlayıcı tarafından veri seti tekrar kodlanmıştır. Ayrıca analiz sürecinde araştırmacılar oluşturdukları temaları, kategorileri ve kodlamaları tekrarlı bir biçimde inceleyerek güvenilirliği arttırmaya çalışmışlardır. Araştırma

20 Matthew B. Miles ve A. Michael Huberman, Qualitative data analysis: An expanded sourcebook (New York: Sage Publications, Inc, 1994). 
sonuçlarının güvenilirliğini arttırmak için Miles ve Huberman (1994) tarafından önerilen kodlayıcı görüş birliğine ilişkin tutarlık ya da araştırma güvenilirliği formülü kullanılmıştır.

\section{Bulgular}

Suriyeli sığınmacı öğrencilerin genel sorunları ile din eğitimine ilişkin sorunlarına yönelik DKAB öğretmen görüşlerine dair bulgular ayrı başlıklar altında bu bölümde yer almaktadır. Bununla birlikte bu bölümde yalnızca veri sunumu yapılacak olup konuya ilişkin literatür tartışmalarına çalışmanın sonraki bölümünde yer verilecektir. Ayrıca tekrara düşmemek veya araştırmanın okunabilirliğini olumsuz yönde etkilememek için alıntılardan en çarpıcı olanları seçilip sunulmuştur.

\section{Genel Sorunlara İlişskin Bulgular}

Bu bölümde $\mathrm{DKAB}$ öğretmenleriyle yapılan mülakatlardan elde edilen verilerin analizinde öncelikle DKAB öğretmenlerine sınıftaki sığınmacı öğrencilerde görülen genel sorunlar hakkında sorular sorulmuş ve gelen cevaplar Tablo 1'de özetlenmiştir.

Tablo 1. Suriyeli Sığınmacı Öğrencilerde Gözlenen Genel Sorunlar

\begin{tabular}{lll}
\hline \multicolumn{1}{c}{ Tema } & \multicolumn{1}{c}{ Kategori } & Sayı \\
\hline \multirow{2}{*}{ Bilişsel Sorunlar } & Algılama güçlüğ̈ & 35 \\
& Sözel becerilerde gerilik & 41 \\
\multirow{3}{*}{ Duyuşsal Sorunlar } & Duygusal sorunlar & 65 \\
& Kaygılı ruh hali & 59 \\
& Dikkat dağınıklı̆̆ı & 72 \\
Davranışsal Sorunlar & Şiddet eğilimi & 68 \\
& Sinıf kurallarına uymama & 74 \\
Gelişimsel Sorunlar & Saldırganlık & 62 \\
& Fiziksel gelişimde gerilik & 37 \\
Sosyal Sorunlar & Dil ve Konuşma bozuklukları & 33 \\
& Arkadaş edinmede zorlanma & 76 \\
& Sadece Suriyelilerle arkadaşlık & 79 \\
& Türkçe konuşamama & 76 \\
\hline
\end{tabular}

Tablo 1 incelendiğinde DKAB öğretmenlerinin Suriyeli sığınmacı öğrencilerde gözlemlediği genel sorunların, bilişsel, duyuşsal, davranışsal, gelişimsel ve sosyal sorunlar olarak belirlenen 5 tema altında toplandığ 1 görülmektedir. DKAB öğretmenlerine göre Suriyeli sığınmacı öğrencilerin bilişsel sorunlarına ilişkin temada algılama güçlüğü $(n=35)$ ve sözel becerilerde gerilik $(n=41)$ yer almaktadır. Duyuşsal sorunlar teması altında dikkat dağınıklığ $(\mathrm{n}=72)$ ön plana çıkarken, davranışsal sorunlardan sınıf kurallarına uymama $(n=74)$ DKAB öğretmenlerinin vurguladığ 1 
sorunlar arasındadır. Tablo 1'de dikkat çeken sosyal sorunlar teması altında, katılımcıların tamamı $(\mathrm{n}=79)$ Suriyeli sığınmacı öğrencilerin sadece Suriyelilerle arkadaşlık kurduğunu ve okula uyum sorunları yaşadıklarını bildirmişlerdir. Konu ile ilgili katılımcı görüşlerinden bazıları aşağıda yer almaktadır:

“...Açıkçası en büyük sorun Suriyelilerin okula uyumu; yalnızca Suriyelilerle arkadaşlık kuruyorlar. Dil bilmediğimiz için onları Türklerle arkadaşlık kurmaya teşvik edemiyoruz. Zaten Türk öğrenciler de onlarla iletişim ve arkadaşlık kurmak istemiyor. Suriyeliler, Türkçe ögrenmek istemiyorlar; her şeyin kendilerine hazır bir şekilde sunulmasına alışmışlar ve bizden de bunu bekliyorlar... Kendilerini ifade etmek yerine, bizim onları anlamamızı bekliyorlar... "(Ö-47).

“...Arapçam sınırlı ama Suriyelilerdeki gelişim sorunlarını görmek için dil bilmeye gerek yok. Çoğunluğu karın tokluğuna çalışan ailelerin çocuklarl; evlerinde ne pişer, ne yer ne içerler bilmiyoruz. Zaman zaman evlerine yardım götürüyoruz ve hangi şartlarda yaşadıklarını az çok görüyoruz. Bu şartlarda gelişim geriliği olması çok doğal...” (Ö-19).

“...Suriyelileri sınıf kurallarına uymaya zorlasak da kuralları öğrenemediler. Sınıf içinde ciddi disiplin sorunları oluyor. Bazı çocuklar ciddi şiddet eğilimine sahip, kendi aralarında kavga ediyorlar ve saldırganlıkları da Suriyelilere yönelik olsa da Türklere de saldırdıkları oluyor. Aslında sarsıntı falan diyoruz ama çoğunluğu sokakta büyüyor... Yani şiddet eğilimi ve saldirganlık çok normal..." (Ö-66).

\section{Din Eğitimine İlişkin Bulgular}

DKAB öğretmenlerinin, sınıftaki Suriyeli sığınmacı öğrencilerin din eğitimine yönelik yaptığı çalışmalarla ilgili görüşleri Tablo 2'de özetlenmiştir.

Tablo 2. Suriyeli Sığınmacı Öğrencilerin Din Eğitimine Yönelik Yapılan Çalışmalar

\begin{tabular}{lc}
\hline \multicolumn{1}{c}{ Din eğitimine yönelik DKAB öğretmenlerinin yaptığı etkinlik ve çalışmalar } & Sayı \\
\hline Herhangi özel bir çalışma yapmıyorum. & 27 \\
Arapça din eğitimi kitapları ile ders dışında ek çalışmalar yapıyorum. & 19 \\
Sınıfı din eğitimi konuları ile ilgili afiş ve diğer görsellerle süsledim. & 17 \\
Din derslerinde Suriyelilere ezan, ilahi veya Kur'an-1 Kerim okutuyorum. & 23 \\
Suriye'deki din eğitimi hakkında bilgi vermeleri için derste süre tanıyorum. & 9 \\
Suriyelilerin dil ve akademik seviyelerine uygun Arapça dini hikâyeler dağıttım. & 17 \\
Suriyelilerle derste birebir ilgileniyor, konuyu ders sonunda Arapça özetliyorum. & 15 \\
Akran öğrenmesi yöntemini uyguluyorum. & 7 \\
\hline
\end{tabular}

Tablo 2'de DKAB öğretmenleri tarafından Suriyeli öğrencilerin din eğitimine yönelik yapılan etkinlik ve çalışmalar incelendiğinde din derslerinde Suriyelilere ezan, ilahi veya Kur'an-1 Kerim okutulması (n=23) ilk sırada yer almaktadır. Arapça din eğitimi kitapları kullanarak ders dışında ek çalışmalar yapılması $(n=19)$ ve sınıfa din eğitimi ile ilgili afiş ve görseller asılması $(n=17)$ ile Suriyeli öğrencilerin dil ve akademik seviyelerine uygun Arapça dini hikâyeler dağıtılması $(n=17)$ sıklıkla yapılan etkinlikler arasındadır. Söz konusu etkinliklerin çoğunlukla Arapça kullanılarak yapılması dikkat çekicidir; bu durum okullarda önemli bir 
Türkçe öğretim sorunu olduğunu belirginleştirmektedir. Konu ile ilgili katılımcı görüşlerinden bazıları aşağıda yer almaktadır:

“...Suriyeliler Türkçe bilmediği için derslerde fazla bir etkinlik gösteremiyorlar, ben de Arapça bilmiyorum; bu yüzden onlara özel çalışma yapmıyorum.” (Ö-22).

“...Arapça din eğitimi kitapları edindim, bu kitaplar yaşlara göre yazılmış ve hangi yaşta ne öğretileceği belirlenmiş; ders dışı bunları okutuyorum Suriyelilere. Ancak çoğunlukla din ögretimi yapabiliyorum bu kitaplarla, bizim müfredatımızda olmayan şeyler var çoğunlukla. Dersleri mescitte yaptığım için ibadetleri de beraber yapıyoruz...” (Ö-53).

“...Din derslerinin girişinde ve öğrenciler sıkllinca Suriyelilerden ezan, ilahi veya Kur'an dinliyoruz. Hem onlar seviniyor hem de Türklerin hoşuna gidiyor. Bir de sinıfi din eğitimi ile ilgili afiş ve fotoğraflarla süsledim. Öğrenciler bu görsellere bakıp farklı kültürleri öğreniyorlar. Suriye'nin savaştan önceki görsellerinden çok etkileniyorlar..." (Ö-17).

“...Suriyeliler için derste anlattı̆̆ım konuları kısa özetler halinde ders sonunda Arapça açıkliyorum. Ayrıca din eğitimi ile ilgili ögrencilerin yaş gruplarına uygun Arapça hikâye kitapları dağıttım. Velilerin de bu kitapları öğrencilere okumalarını istiyorum. Yöntem oldukça etkili oldu, derste ögrenciler daha ilgili...” (Ö-59).

“...Akran ögrrenmesi yöntemi var. Öğrenciler birbirlerinden ögrreniyorlar, özellikle Kur’an derslerinde çok işe yaradı. Suriyeliler derste herkese yardım ederek Arapça okuma sorunlarını çözüyorlar. Bu öğrencileri mutlaka böyle işe yarayacakları şeylerde kullanmallyız. Kendilerini önemli hissetmeliler..." (Ö-71).

\section{Din Öğretimi Müfredatına İlişkin Bulgular}

DKAB öğretmenlerinin okullarda uygulanan din öğretimi müfredatının Suriyeli sı̆̆ınmacı öğrencilere ilgili görüşleri Tablo 3 ’te özetlenmiştir.

Tablo 3. Okullarda Uygulanan Din Öğretimi Müfredatının Suriyeli Öğrencilere Uygunluğu

\begin{tabular}{lc}
\hline \multicolumn{1}{c}{ Din öğretimi müfredatının uygunluğu } & Sayı \\
\hline Türk öğrencilere uygun ama Suriyeli öğrencilere uygun değil. & 72 \\
Mezhep farklılıklarını dikkate alan müfredat gereklidir. & 41 \\
Suriyeli öğrencilerin uyum sorununa odaklanan alternatif bir müfredat olmalıdır. & 69 \\
İslam değerlerine uygun yeni bir din öğretimi müfredat hazırlanmalıdır. & 62 \\
Suriyelilerin inanç sorunlarına yönelik bir müfredat hazırlanmalıdır. & 39 \\
Suriyelilerin manevi ihtiyaçlarını gözeten bir din öğretimi müfredat hazırlanmalıdır. & 53 \\
Müfredat yeterlidir; yeni bir müfredat hazırlanması gerektiğine inanmıyorum. & 7 \\
\hline
\end{tabular}

Tablo 3'e göre öğretmenlerin büyük çoğunluğu (n=72), din öğretimi müfredatının Türk öğrencilere uygun ama Suriyeli öğrencilere uygun olmadığını düşünmektedir. Öğretmenlere göre, Suriyeli öğrencilerin uyum sorununa odaklanan alternatif bir din öğretimi müfredatı olmalıdır ( $\mathrm{n}=69$ ). Ayrıca evrensel İslam değerlerine uygun yeni bir din öğretimi müfredatı hazırlanması $(n=62)$ ile Suriyelilerin manevi ihtiyaçlarını gözeten bir din öğretimi müfredatının hazırlanması gerektiğine $(n=53)$ yönelik 
öğretmen görüşleri önem arz etmektedir. Konu ile ilgili katılımcı görüşlerinden bazıları aşağıdadır:

“...Din öğretimi müfredatı çok değişikliğe uğradl, şimdilik kültürlerarası ve dinler üstü bir formda. Ancak Suriye'de bu çocuklar medrese veya yoğun dini öğretim almışlar. Bizim dersler onlara anlamsız geliyor. Mezhepler üstü yaklaşımın çöktüğ̈̈ne de tanık olmuş bu öğrenciler Suriye savaşında, yani bizim sadeleştirilmiş din öğretim programımız Türk ögrencilere hitap etse de Suriyelilere hitap etmiyor... Suriyelilerin topluma uyumuna odaklanan, mezhep farklılıklarını dikkate alan ama manevi ihtiyaçları da gözeten yeni bir din öğretimi müfredatı gerekiyor..."(Ö-72).

“...Suriyeliler mezhep farklılarını yaşayarak gelmişler buraya, savaşın yönü mezheplere ve dini ayrılıklara çevrildiğinde çok sayıda sı̆̆ınmacı geldi ülkemize: Yezidiler, Süryaniler, Aleviler... Mezhepsel farklılıklar önemli onlar için. Çoğunun ailesi de bu farklılı̆̆ sürdürmek istiyor. Bizim din öğretimi müfredatımız genel kanı oluşturuyor. ... Yeni bir müfredat yazılmalı, sapkın mezheplerin ayrışması hakkında gerçeklerin yazıldı̆̆g ve öğretildiği bir müfredat... "(Ö-41).

“...Müfredatımı kesinlikle eksik ve yeterli değil, güncel din ihtiyaçlarını karşılamaktan da oldukça uzakta... Evrensel İslam değerlerine uygun yeni bir din ögretimi müfredatına ihtiyaç var. Hem Suriyelilerin hem de Türk ögrencilerin manevi ihtiyaçlarına uygun, yabancıların bizim toplumumuza uyumuna katkı bir müfredat..." (Ö-62).sunacak

\section{Din Eğitimine Engel Durumlara İlişkin Bulgular}

DKAB öğretmenlerinin okullarda Suriyeli öğrencilere din eğitimi vermeye engel teşkil eden durumlarla ilgili görüşleri Tablo 4'te özetlenmiştir.

Tablo 4. Suriyeli Sı̆̆ınmacı Öğrencilere Din Eğitimine Engel Durumlar

\begin{tabular}{lc}
\multicolumn{1}{c}{ Din eğitimine engel durumlar } & Sayı \\
\hline Suriyelilerin Türkçe bilmemesi; Türkçe öğrenmeye isteksiz olması & 79 \\
DKAB öğretmenlerinin yeterince Arapça bilmemesi & 79 \\
DKAB öğretmenlerinin yabancı öğrencilerle çalışma konusunda yetersiz olması & 79 \\
Velilerin, öğrencilere din eğitimi verilmesine karşı olumsuz tutumları & 32 \\
Mezhepsel farklılıklar & 64 \\
Suriyelilerin dine karşı aşırı eleştirel olmaları & 74 \\
Suriyelilerin bizim dini yaklaşımımızı öğrenmek istememeleri & 76 \\
Suriyeli öğrencilerin derslere düzenli olarak devam etmemesi & 68 \\
Suriyeli öğrencilerin seküler yaşama özenmesi ve dine yönelik ilgisizliği & 65 \\
\hline
\end{tabular}

Tablo 4 incelendiğinde, katılımcı öğretmenlerin tamamı $(n=79)$, Suriyelilerin Türkçe bilmemesinin, Türkçeye öğrenmeye isteksiz olmasının, DKAB öğretmenlerinin yabancı öğrencilerle çalışma konusunda yetersiz olmasının ve DKAB öğretmenlerinin yeterince Arapça bilmemesinin okullarda din eğitimi verilmesine engel olduğunu düşünmektedirler. Ayrıca öğretmenler, Suriyelilerin dine karşı eleştirel olmasının ( $\mathrm{n}=74)$, seküler yaşama özenerek dine yönelik ilgisizliğinin $(n=65)$ ve devamsızlık sorunlarının $(n=68)$ da Suriyelilere okullarda etkili din 
eğitimi verilmesine engel durumlar arasında olduğunu düşünmektedir. Konu ile ilgili katılımcı görüşlerinden bazıları aşağıda sunulmuştur:

“...Suriyeliler Türkçe bilmiyor, ögrenmeye de isteksizler... Ben de Arapça bilmiyorum ve öğrenmeye de isteksizim. Bu önemli bir sorun, çünkü birbirimizi anlamıyoruz...” (Ö-11).

“...Lisans öğrenimi boyunca doğru düzgün eğitim bilimleri dersleri almadık. Değil yabancı ögrenciler, Türk ögrrencilere bile öğretim yapmayı okulda, iş başında ögrrendik. Yabancı ögrencilerle çalışmayı bilmiyoruz..." (Ö-34).

“...Toplumsal gerilimler var, önyargılar var; Suriyeliler bizi sevmiyor, açıkçası bizimde onlarla aşk yaşadığımız söylenemez. ...Toplumsal gerginler sebebi ile Suriyeliler kendi kültürlerini korumak istiyorlar, geri dönmeyeceklerini onlar da biliyor. Bizim değerlerimizin kendilerini asimile edeceğini düşünüyorlar. Bunun önemli bir şekli de din elbette... Suriyeli veliler bizim dini eğitimimizi sorguluyorlar, sanki biz başka bir Íslam' l anlatıyormuşuz gibi davranıyorlar. Bu durum öğrencilere yansiyor. Öğrenciler din derslerine ilgisiz ve seküler yaşantıya meylediyorlar. Dini eleştiriyorlar, din derslerinde bizi eleştiriyorlar, sürekli eleştiriyorlar...” (Ö-65).

“...Devamsızlık önemli bir sorun. Öğrencilerin çoğu yol kenarında dileniyor. Yaşı büyük olanlar, abileri ve babalart ile işe gidiyor. Arada strada okula geliyorlar. Elbette sokak kültürüne aşina olan çocuk, aynı kültürü okula taşıyınca önemli disiplin sorunları yaşanıyor. Giyim tarzları ile seküler yaşantı özentisi çok yaygın, ileride nerede nasıl yaşamak istersiniz diye sorduk. Çoğunluğu seküler bir yaşantı istiyor ve Bebek'te, Nişantaşı'nda lüks bir hayat hayali kuruyor; çok azı İslami geleneğe uygun yaşamak istediğini söyledi...” (Ö-40).

\section{Din Derslerinde Yaşanan Disiplin Sorunlarına İlişkin Bulgular}

DKAB öğretmenlerinin din derslerinin akışını engelleyen veya bu derslerde Suriyeli öğrencilerle yaşadıkları disiplin sorunları ilgili görüşleri Tablo 5’te özetlenmiştir.

Tablo 5. Din Derslerinde Yaşanan Disiplin Sorunları

\begin{tabular}{lc}
\hline \multicolumn{1}{c}{ Din derslerinde yaşanan disiplin sorunları } & Sayı \\
\hline Dersi dinlememe ve kendi aralarında sürekli konuşma & 79 \\
Dersin anlatışını veya öğretmeni sabote etme & 66 \\
Ders sürecinde sınıf arkadaşları ile kavga ve küfür etme & 73 \\
Sınıf kurallarına uymama & 78 \\
Sınıf içinde dolaşma & 75 \\
Türk öğrencilerin Suriyelilere karşı önyargılarının olması & 79 \\
Sınıf arkadaşlarını kıskanma & 71 \\
Dersi dinleyen diğer arkadaşlarının dikkatini bozma & 72 \\
\hline
\end{tabular}

Tablo 5 incelendiğinde, DKAB öğretmenleri, din derslerinde Suriyeli öğrencilerin disiplin sorunları olarak dersi dinlemediği ve kendi aralarında konuştuklarını $(\mathrm{n}=79)$, Türk öğrencilerin Suriyelilere karşı önyargılarının olduğunu ( $\mathrm{n}=79)$, Suriyeli öğrencilerin sınıf kurallarına uymadıklarını $(\mathrm{n}=78)$ ve sınıf içinde dolaştıklarını $(\mathrm{n}=75)$ bildirmişlerdir. Ayrıca öğretmenler, derste öğretmeni sabote 
etme, arkadaşlarının dikkatini bozma, sınıf içinde arkadaşlarıyla kavga ve küfür etme ile arkadaşlarını kıskanma gibi durumların da sınıf içi disiplini bozduğunu belirtmişlerdir. Konu ile ilgili katılımcı görüşlerinden bazıları aşağıdadır:

“...Disiplinsiz bir sinıfa değil din eğitimi, herhangi bir dersin anlatılabileceğini düşünmüyorum. Suriyelilerin çoğunlukta olduğu sinıflarda disiplini sağlamak çok zor oluyor. Dersi dinlemedikleri gibi sürekli konuşuyorlar. Susturmak için hemen her yola başvuruyoruz ama yine de yapamiyoruz. Sertlik ve dayak temelli Suriye eğitiminden bahsediyorlar, orada dayak bir terbiye metodu olarak kullanılırmış, bizden de aynı şekilde sert davranmamızı bekliyorlar. Sinıfiçinde dolaşma, kavga etme, küfür etme gibi şeyler çok siradan..." (Ö-30).

“...Dersin anlatışını bozuyorlar, dahası benim dersi anlatmama engel oluyorlar. Sinıfa arkamı dönemiyorum. Arkamı döndüğ̈̈mde hemen bir ses çıkaran, arkadaşına küfreden veya kavga eden Suriyelileri görüyorum ya da bir anda sınıf içinde dolaşmaya başlayan, ağlayan veya lavaboya kaçan çocuklarla uğraşmak zorunda kalıyorum... "(Ö-55).

“...Suriyeliler sinıf kurallarına uymuyorlar. Kentli olmanın gereklerini bilmiyorlar, yani bir kişi konuşurken susup onu dinlemenin önemini bir türlü kazandıramıyoruz onlara. Arkadaşlarını kıskanıyorlar ve kıskançlık temelli kavgalar sı oluyor. Ders işlenirken bir anda bir ses çıkartıyor veya sınıftan çıklyor; o anda sınıfin tüm dikkati dağllıyor ve sinıfi tekrar derse güdülemek çok zor oluyor. Sinıf içi disiplini sağlamak için ya bağırmak ya da dövmek gerekiyor ki bu durumda hemen şikâyet ediliyoruz..." (Ö-69).

\section{Din Derslerinde Yaşanan Eğitim Sorunlarına İlişkin Bulgular}

DKAB öğretmenlerinin, Suriyeli sığınmacı öğrencilerin çoğunlukta olduğu sınıflardaki din derslerinde yaşanan eğitim sorunlarına ilişkin görüşleri Tablo 6'da özetlenmiştir.

Tablo 6. Din Derslerinde Yaşanan Eğitim Sorunları

\begin{tabular}{lc}
\hline \multicolumn{1}{c}{ Din derslerinde yaşanan eğitim sorunları } & Sayı \\
\hline Başarısızlığa tahammülsüzlük & 65 \\
Din derslerine karşı olumsuz tavır ve ilgisizlik & 79 \\
Devamsızlık nedeniyle dersleri takip etmekte zorlanma. & 78 \\
Suriyeli öğrencilerin mezhep farklılıklarını ön plana çıkarmaları & 74 \\
Suriyeli öğrenciler ile Türk öğrenciler arasındaki akademik seviye farkı & 69 \\
Suriye ve Türkiye'deki din öğretimi müfredatı farklılı̆̆ı & 77 \\
Suriyelere din derslerinin nasıl anlatıllacağının bilinmemesi & 73 \\
\hline
\end{tabular}

Tablo 6 incelendiğinde, DKAB öğretmenlerinin tamamı $(\mathrm{n}=79)$, Suriyelilerin din derslerine karşı olumsuz tavır sahibi olduğunu, derslere ilgisiz olduğunu bildirmişlerdir. Ayrıca öğretmenler din derslerinde yaşanan eğitim sorunları olarak Suriyeli öğrencilerin devamsızlık nedeniyle dersleri takip etmekte zorlandığını $(\mathrm{n}=78)$, Suriye ve Türkiye arasındaki din öğretim müfredatının farklı olmasını $(n=77)$, mezhep farklılıkları nedeniyle din eğitimi sorunları yaşandığını $(n=74)$ ve yabancılara din dersinin nasıl anlatılacağının bilinmediğini $(\mathrm{n}=73)$ bildirmişlerdir. 
Konu ile ilgili katılımcı görüşlerinden bazıları aşağıda verilmiştir:

“...Suriyelilerin din derslerine karşı ilgisiz olması en büyük sorun bence. Derste Arapça kelimeler geçtiğinde seviniyorlar, çünkü bildikleri kavramlar anlatıliyor ama Türkçe bilmediği için derse katılmıyor ve ilgisiz bir şekilde başka şeylerle ilgileniyor. Sınava giriyor, düşük not alıyor çünkü okuma-yazma bilmiyor, sadece testi işaretliyor. Düşük not alınca buna da tahammül edemiyor, sinavin adaletini sorguluyor, sistemi ve kaderini sorguluyor...” (Ö-5).

“...Çocuklar çalı̧̧ınca derse gelemiyorlar, sınıfta kalma da yok, derse arada sırada geliyorlar. Isınmak için derse geliyoruz diyenler oldu, hal böyle olunca derse katılımları da zorlaşıyor... Bir de mezhep vurgusu çok fazla çocuklarda. Her şeyi mezhepsel farklıliklarla çözme anlayışındalar. Tarikatlar bunu çok iyi anlamış, Suriyelileri devşirmek için uğraşıyorlar. Tabi ki tarikatlarda Arapça bilen çok kişi var ve bunlar Suriyelilere yalan yanlış din eğitimi veriyorlar. Bu çok ciddi bir sorun ..." (Ö-16).

“...Suriyeliler okuma-yazma ve Türkçe bilmediği için onların akademik seviyesinin tam olarak ne olduğunu bilmiyoruz. Sinavlart test yapınca belirli notlar allyorlar, ancak Türk ögrencilerle aralarında önemli akademik başarı farkı var. Ayrıca Suriye'de bambaşka bir müfredat var, din ögretimi daha farklı ve çoğunlukla mahalle medreselerinde eğitim allyorlar. Köylerde ise medreseler daha yaygin ve din ögretimleri daha radikal yönelimlerde olabiliyor. Bizim dinler üstü, mezhepler üstü ve kültürel farklılara yönelik eğitim anlayışımı Suriyelilere hitap etmiyor. Bir de bizim din öğretimi müfredatımız çok sınırlandırıyor bizleri, yabancı ögrencilere dersin nasıl anlatılacă̆ını bilmiyoruz. Onlara yönelik hangi öğretim yöntem ve teknikleri var bilmiyoruz..." (Ö-27).

\section{Din Kültürü ve Ahlak Bilgisi Öğretmenlerinin Önerilerine İliş̧in Bulgular}

DKAB öğretmenlerinin, Suriyeli sığınmacı öğrencilerin din eğitimi sorunlarının çözümü için önerileri Tablo 7'de özetlenmiştir.

Tablo 7. Suriyeli Öğrencilerin Eğitimi Konusunda DKAB Öğretmenlerinin Önerileri

\begin{tabular}{lc}
\hline \multicolumn{1}{c}{ DKAB öğretmenlerinin önerileri } & Sayı \\
\hline Velilere ve öğrencilere Türkçe öğrenmeleri sağlanmalıdır. & 79 \\
Velilere ve öğrencilere İlk Okuma-yazma kursları düzenlenmelidir. & 79 \\
Velilere ve öğrencilere kültürel ve sosyal uyum becerileri kazandırılmalıdır. & 79 \\
Velilere ve öğrencilere yönelik manevi danışmanlık hizmetleri verilmelidir. & 75 \\
Suriyeli öğrencilerin devamsızlık durumlarının azaltılması için önlem alınmalıdır. & 67 \\
Suriyeli öğrencilere yönelik daha caydırıcı cezalar verilmelidir. & 61 \\
Öğrencilere psikolojik destek verilmelidir. & 58 \\
Karşılıklı önyargıların azaltılması için empati eğitimleri verilmelidir. & 76 \\
Kendi dil ve kültürlerine uygun eğitim verilmelidir. & 43 \\
Suriyeliler için ayrı öğretim programlarının uygulandığı okullar açılmalıdır. & 43 \\
Din öğretimi müfredatı yenilenmelidir. & 79 \\
\hline
\end{tabular}

Tablo 7 incelendiğinde, DKAB öğretmenlerinin tamamı $(\mathrm{n}=79)$, Suriyeli veli ve öğrencilere Türkçe, okuma-yazma, kültürel ve sosyal uyum eğitimleri verilmesi ve din öğretimi müfredatının yenilenmesi gerektiğini önermektedirler. Ayrıca öğretmenler, veli ve öğrencilere manevi danışmanlık $(\mathrm{n}=75)$, önyargıların azaltılması 
için empati eğitimi ( $n=76)$ ve devamsızlık sorununun çözümü $(n=67)$ için çalışmalar yapılmasını da önermektedirler. Konu ile ilgili katılımcıların önerilerinden bazıları aşağıda sunulmuştur:

“...Din öğretimi müfredatt, Suriyelilerin din eğitimi sorunlarını çözecek esneklikte değil. Ayrıca günümüzün dini sorunlarına da yönelmiyor, insanlara 'doğru din nedir?'sorusunun cevabın anlatacak bir öğretim yaklaşımı bu müfredatta yer almiyor..." (Ö-36).

“...Suriyelilerin tamamının Türkçe öğrenmeleri gerekiyor. Topluma uyum eğitimi almaları, beraber yaşamayı öğrenmeleri ve şehrin ve okulun kurallarına riayet etmeyi de öğrenmeleri gerekli. Okulumuzun yanındaki sokaktan geçemiyoruz, çünkü sokaklara taşan bir kahvehaneleri var, belediye müdahale etmiyor ve onlarda yoldan gelen geçen herkesi taciz ediyorlar. Suriyelilere bu ülkenin modern ve medeni kuralları öğretilmeli. Okul içinde istediğini yapıyor Suriyeli öğrenci, doğru düzgün ceza da almıyor. Caydırıcı cezalar olmalı, Türk öğrenciye uyguladığımız yöntemleri Suriyelilere de uyguladığımızda okul yönetimi bize çıkışıyor. Neden böyle yaptınız, onlar misafirimiz falan deniyor. Esasen uyum sağlamak istemeyenler için Arapça eğitim veren okullar açılsa, bu öğrenciler orada eğitim görse veya en azından kendi müfredatların uygulasak daha iyi olmaz mı? Zaten dönmeyeceklerini bildiğimiz için bu öneri çok havada kalıyor. Buraya uyum sağlamak zorundalar, Türkçe öğrenmek ve bizimle yaşamayı öğrenmek zorundalar. Okuma ve yazma sorunları diğer bir sorun, bence acil bir okuma-yazma kampanyasl yapılmalı bu kişiler için... Ayrıca, çoğu Suriyeli dini konularda çelişkili düşüncelere sahip, manevi danışmanlık hizmetleri sunulmalı bu kişiler için. Kişiler derken veli ve öğrencileri kast ediyorum. Mezhep farklılıklarını azaltıcı, önyargılardan arınmış bir empati eğitimi ile toplumsal düzene uymaları sağlanabilir..." (Ö-7).

“...Suriyeliler okul dışında para kazanınca bundan vazgeçmeleri zor oluyor, çünkü okulda sadece sinırl yardım vs. yapıliyor. Sokakta çalışan çocuğu okula getirmek zor oluyor, devamsızlık sorunu yaşıyorlar ama ölmedikçe ya da başlarına bir iş gelmedikçe okul yönetimi de umursamıyor onların devamsızlığını... Bence devam sorunu kolay çözülecek gibi durmasa da önce oradan başlamalıyı ve onlara okulu sevdirmeliyiz..." (Ö-50).

\section{Tartışma ve Sonuç}

$\mathrm{Bu}$ araştırmada din kültürü ve ahlak bilgisi (DKAB) öğretmenlerin Suriyeli sığınmacı çocukların din eğitiminde karşılaştıkları problemler, din eğitimine engel teşkil eden durumlar ve öğretmenlerin problemlerin çözümüne yönelik önerileri araştırılmıştır.

$\mathrm{Bu}$ araştırmada $\mathrm{DKAB}$ dersi öğretmenlerinin, Suriyeli öğrencilerin din eğitimini sağlayabilmek için çeşitli çalışmalar yaptığı belirlenmiştir. Buna göre, Arapça din öğretimi ders kitapları veya dini hikâyeler ile etüt eğitimleri yapıldığı görülmektedir. Ayrıca öğretmenler, dersin son bölümlerinde Arapça özet yapmakta veya Suriyeli öğrencilere ilahi, ezan veya Kur'an-1 Kerim okutmaktadırlar. Suriyeli öğrencilerin böylesi etkileşimli etkinliklerle derse katılımının sağlanması önemlidir. Çünkü bu öğrencilerin Türkçe eğitime karşı ilgisiz olduğuna yönelik araştırmalar 
bulunmaktadır. ${ }^{21}$ Özellikle Suriyelilerin güçlü olduğu alanlara odaklanılarak din eğitiminde akran öğrenmesi yapıldığına yönelik araştırma bulgusu önem taşımaktadır. Akran öğrenmesi, öğrencilerin birbirlerinden öğrendikleri çağdaş öğretim yöntemlerinden birisidir. ${ }^{22}$ Yabancı öğrencilere din eğitimi verilmesinde bu yöntem etkin olarak kullanılabileceği gibi empati veya önyargıların azaltılmasına yönelik eğitimlerde de akran öğrenmelerinden yararlanılabilir. Araştırma kapsamında DKAB öğretmenleri, sınıfları çeşitli dini görsel ve afişleri süslediklerini ve böylece öğrencilerde ortak bir ümmet algısı oluşturmaya çalıştıklarını bildirmişlerdir. $\mathrm{Bu}$ çalışma özellikle aynı inanışlara sahip bireyleri birbirlerine yaklaştırması açısından önem taşır ve desteklenmesi gereklidir. Din eğitiminin önemli bir işlevi birey-grup etkileşimini din temelli sağlamak ve bireylerin dini değerleri içselleştirerek evrensel bir bütünlüğe ya da ümmet bilincine erişmelerini kolaylaştırmaktır.

Ayrıca öğretmenler, Türkçe dil sorununun din eğitimi vermeye engel olduğunu, $\mathrm{DKAB}$ öğretmenlerinin yeterince Arapça bilmediklerini ve öğretmenlerin yabanc1 öğrencilerle çalışmaya yatkın olmadıkları yönünde görüş belirtmişlerdir. Bu noktada literatürde benzer sonuçlara ulaşan çalışmalar olduğu belirlenmiştir. ${ }^{23}$ Dil sorunu genel eğitimi olduğu kadar din eğitiminin de sunumunu engellemektedir. Bu açıdan gerek öğretmenlerin yabancı dil öğrenmesine yönelik hizmet içi faaliyetler gerekse sığınmacıların Türkçe öğrenmesinin hılandırılması için çalışmaların yapıldığı bilinmektedir. ${ }^{24} \mathrm{Bu}$ araştırma kapsamında sınıflarda yürütülen din öğretimi etkinliklerini olumsuz etkileyen disiplin sorunları da belirlenmiştir. Buna göre, Suriyeli öğrencilerin dersi dinlememesi ve kendi aralarında sürekli konuşması ile Türk öğrencilerin Suriyelilere yönelik önyargıları en önemli disiplin sorunudur. Ayrıca sınıf kurallarına uymayan, sınıf içinde dolaşan, arkadaşları ile kavga eden öğrenciler de sınıf içi disiplini olumsuz etkilemektedir. Araştırmanın söz konusu bulgusu literatürdeki farklı çalışmalarla benzerlik göstermektedir. Altıntaş, şiddetin önemli bir din eğitimi engeli olduğunu belirlemiş ve okullarda sürdürülen eğitim faaliyetlerinde bu durumun önemli bir disiplin sorunu oluşturduğunu dile getirmiştir. ${ }^{25}$

21 Akkaya, "Suriyeli Mültecilerin Türkçe Algıları",185.

22 Mehmet Taşpınar, Kuramdan uygulamaya öğretim ilke ve yöntemleri (Ankara: Pegem A Yayınc1lık, 2017), 69.

23 Aybiçe Tosun vd., "Mülteci öğrencilerin eğitim sorunları, eğitim ve din eğitiminden beklentileri: Eskişehir örneği”, Eskişehir Osmangazi Üniversitesi Sosyal Bilimler Dergisi 19, sy 1 (2018): 107-33; Muhammed Esat Altıntaş, "DKAB Öğretmenlerine Göre Suriyeli Çocukların Devlet Okullarında Karşılaştıkları Sorunlar (Nitel Bir Araştırma)”, Marife, 2018, 491.

24 Ahmet Selman Özdemir, “Türkçe Eğitim Merkezi - Mülteciler Derneği”, erişim 17 Haziran 2019, https://multeciler.org.tr/turkce-egitim-merkezi/.

25 Altıntaş, "DKAB Öğretmenlerine Göre Suriyeli Çocukların Devlet Okullarında Karşılaştıkları Sorunlar (Nitel Bir Araştırma)", 483-484. 
Moralı ise dil ve uyum sorunları yaşayan Suriyeli çocukların okullarda yoğun disiplin sorunları oluşturduğunu belirlemiştir. ${ }^{26}$ Ayrıca araştırma kapsamında din öğretimi etkinliklerini olumsuz etkileyen eğitsel faktörler de belirlenmiştir. Buna göre, öğrenciler arasındaki akademik seviye farklılığı, öğretmenlerin din öğretimi yöntem ve tekniklerini bilmemesi, mezhep farkl11ıkları ile din öğretimi müfredatının sınırlılıkları DKAB öğretmenleri tarafından eğitsel sorunlar kapsamında değerlendirilmiştir.

DKAB öğretmenlerinin Suriyeli öğrencilerin din eğitimi konusundaki önerileri çoğunlukla dil ve uyum becerilerinin arttırılmasına yönelik eğitim verilmesi ile önyargıların azaltılması bağlamında ele alınabilecek beraber yaşama kültürünün oluşturulması yönündedir. Literatürde Green (2017) göçmen ve sığınmacıların eğitiminde dil bilmemenin temel sorun olduğunu, dil eğitiminin sunulması ile göçle ilgili pek çok sorunun çözümlenebileceğini bildirmiş; misafir ülkelerin etkili dil öğretimi yapmasını önermiştir. ${ }^{27}$ Baltacı (2017), sığınmacıların uyum sorunlarının aşılmasında onlara sunulan dil eğitiminin önemli olduğunu; uyum programlarının mutlaka dil eğitimi ile başlaması gerektiğini bildirmektedir. ${ }^{28}$ Türkiye' de birçok ilde UNICEF işbirliğiyle geçici eğitim merkezlerinde ve MEB'e bağlı okullarda haftada 15 saate kadar, yetişkin ve çocuklara Türkçe dil eğitimi verilmekte ve olanaklar çerçevesinde okuma-yazma kursları ile mesleki eğitim kursları açılmaktadır. ${ }^{29}$ Ancak literatürde geçici eğitim merkezlerinin 2020 y1lı sonuna kadar kademeli olarak kapanacağı ve sığınmacıların, Türklerle aynı okullarda ve ortak müfredatla, Türkçe eğitim alacakları konusunda görüşler bulunmaktadır. ${ }^{30}$ Böylesi bir tahayyülün sığınmacıların dil gelişimine katkı sunacağı, akademik başarılarını arttıracağı ve uyum sorunlarını azaltacağı düşünülebilir. Ancak bütünleşmeden Türk öğrenci ve ailelerinin nasıl etkileneceği, eğitim sistemi içinde söz konusu farklılığın nasıl yönetileceğine yönelik çalışmaların yapılması gereklidir.

26 Gürkan Moralı, "Suriyeli mülteci çocuklara Türkçenin yabancı dil olarak öğretiminde karşılaşılan sorunlar”, Uluslararası Toplum Araştırmaları Dergisi 8, sy 15 (2018): 1426-1449.

27 Molly Green, "Language barriers and health of Syrian refugees in Germany", American journal of public health 107, sy 4 (2017): 486.

28 Ali Baltaci, “A Comparison of Syrian Migrant Students in Turkey and Germany: Entrepreneurial Tendencies and Career Expectations.", European Journal of Educational Research 6, sy 1 (2017): $15-27$.

29 Tanrıkulu, "Türkiye'de yaşayan Suriyeli çocukların eğitim sorunu ve çözüm önerileri”, 29.

30 Ömer Yavuz ve Sefa Mızrak, “Acil durumlarda okul çağındaki çocukların eğitimi: Türkiye'deki Suriyeli mülteciler örneği”, Göç Dergisi 3, sy 2 (2016): 175-199; Bilhan Kartal, “Türkiye’ye yönelik Suriyeli göçünün çok yönlü doğasına giriş”, içinde Beklenmeyen Misafirler: Suriyeli Sığınmacılar Penceresinden Türkiye Toplumunun Geleceği (Transnational Press London, 2018), 13-29. 
Din eğitimin önemli bir parçası olan müfredat, öğretimin yönünü belirlemesi açsından önemlidir. DKAB öğretmenlerinin yabancılara yönelik din öğretiminde uyguladıkları MEB müfredatını yeterli bulmaması, din eğitimi için güncel sorunlara göre düzenlenmiş, esnek ve dinamik bir müfredatı gerektirmektedir. Sığınmacıların okula uyum problemleri, kendini ifade etmede yaşadığ 1 güçlükler, şiddet eğilimli olmaları, yaşadıkları duygusal sorunlar ile arkadaşlık kurmada sıkıntı çekmeleri gibi sorunların çoğu sosyal-duygusal gelişime bağlı sorunlar olduğundan öğrencilerin söz konusu ihtiyaçlarını gözeterek hazırlanacak bir din öğretimi müfredatıyla söz konusu sorunlar azaltılabilir.

Sonuç olarak elde edilen bulgular Suriyeli sığınmacı öğrencilerin dil problemleri ve uyum sorunları olduğunu, ayrıca din derslerine karşı ilgilerinin az olduğunu göstermektedir. Bununla birlikte din öğretimi müfredatında ve din eğitimi etkinliklerinde sığınmacı öğrencilerin din eğitimlerine yönelik düzenlemelere gidilmediği belirlenmiştir. Bu öğrencilere din eğitimi veren öğretmenlerin yabanc1 öğrencilerle nasıl çalışılacağı konusunda eğitilmeleri gerekmektedir. MEB'in öğretmenleri din eğitimi sürecinde aktif olarak desteklemesi önemlidir. Çocukların din eğitimine katılım oranlarının arttırılması, sınıf ortamının din öğretiminin etkili olması için düzenlenmesi ve din derslerine velilerin olumlu tavır almasının sağlanması, Türkçe ve okula uyum problemlerinin çözümlenmesi bakımından etkili olacaktır. Bu süreçte korku, kaygı, saldırgan davranışlar ve şiddet içerikli davranış sergileyen sığınmacı öğrencilere psikolojik destek ve manevi rehberlik hizmetlerinin de etkili bir şekilde sağlanması gerekmektedir. Bununla birlikte özellikle ilk kademelerdeki din eğitimi sorunlarının azaltılması amacıyla sı̆̆ınmacıların öncelikle okul öncesi eğitime yönlendirilmeleri, onlara yönelik çok kültürlü bir din öğretimi müfredatı geliştirilmesi, sığınmacılara eğitim verecek DKAB öğretmenlerinin daha fazla desteklenmesi önerilebilir.

Finansal Destek: Yazar bu çalışma için finansal destek almamıştır.

\section{Kaynakça/References}

Akkaya, Ahmet. “Suriyeli mültecilerin Türkçe algıları.” Ekev akademi dergisi 56, sy 56 (2013): 179-190.

Altaş, Nurullah. Gençlik döneminde din olgusu ve liselerde din öğretimi. Nobel, 2004.

Altıntaş, Muhammed Esat. "DKAB öğretmenlerine göre suriyeli çocukların devlet okullarında karşılaştıkları sorunlar (nitel bir araştırma).” Marife 18, sy 2 (2018): 469-499.

Aşıkoğlu, Nevzat. "Din öğretiminde öğretmenin rolü ve din dersi öğretmeni yeterlilikleri (Türkiye örneği)." Cumhuriyet Üniversitesi İlahiyat Fakültesi Dergisi 15, sy 1 (2011): 5-13.

Baltac1, Ali. "Din kültürü ve ahlak bilgisi öğretmenlerinin örgütsel adalet algısı ve iş doyum düzeyleri arasındaki ilişki.” İn̈nü Üniversitesi Eğitim Bilimleri Enstitüsü Dergisi 6, sy 11 (2019): 28-49. 
—. "Nitel araştırmalarda örnekleme yöntemleri ve örnek hacmi sorunsalı üzerine kavramsal bir inceleme.” Bitlis Eren Üniversitesi Sosyal Bilimler Enstitüsü Dergisi 7, sy 1 (2018): 231-274.

_. "Nitel veri analizinde Miles-Huberman modeli." Ahi Evran Üniversitesi Sosyal Bilimler Enstitüsü Dergisi 3, sy 1 (2017): 1-15.

Baltaci, Ali. "A comparison of Syrian migrant students in Turkey and Germany: Entrepreneurial tendencies and career expectations." European Journal of Educational Research 6, sy 1 (2017): 15-27.

Batar, Yusuf. Empatik din eğitimi. Elips Kitap, 2011.

Bilgin, Beyza. Türkiye'de din eğitimi ve liselerde din dersleri. Emel Matbaacılık, 1980.

Bircan, Tuba. "Educational assessment of Syrian refugees in Turkey." Migration Letters 12, sy 3 (2015): 226-237.

Boyraz, Zeki. “Türkiye'de göçmen sorununa örnek Suriyeli mülteciler.” Zeitschrift für die Welt der Türken/Journal of World of Turks 7, sy 2 (2015): 35-58.

Cardinal, Monique C. "Religious education in Syria: unity and difference." British Journal of religious education 31, sy 2 (2009): 91-101.

Creswell, John W. Educational research: Planning, conducting, and evaluating quantitative. Prentice Hall Upper Saddle River, NJ, 2002.

Culbertson, Shelly, ve Louay Constant. Education of Syrian refugee children: Managing the crisis in Turkey, Lebanon, and Jordan. Rand Corporation, 2015.

Doğan, Recai, ve Nurullah Altaş. "Din öğretiminde yeni yöntem tartı̧̧malarında kuramdan uygulamaya: İlköğretim din kültürü ve ahlak bilgisi programları (Ankara modeli)." Değerler Eğitimi Dergisi 2, sy 5 (2004): 23-38.

Dörtkardeş, İhsan. “'Suriyeli öğrenciler imam hatiplere yönlendirilsin' genelgesi - Son Dakika Flaş Haberler. Erişim tarihi: 18 Nisan 2019. https://www.cnnturk.com/turkiye/suriyeli-ogrencilerimam-hatiplereyonlendirilsin-genelgesi.

Duman, Betül. "Yoğun göç almış metropollerde etniklik ve öteki ile ilişki.” Sosyoloji Dergisi 3, sy 27 (2013): 1-24.

Emin, Müberra Nur. “Türkiye’deki Suriyeli çocukların eğitimi: Temel eğitim politikaları”. Seta, 2016.

F1stık, Fırat. "Suriyelilerin kaldığı çadır kentler kapatılıyor, gelecekleri belirsiz”. Medyascope. Erişim: 22 Nisan 2019. https://medyascope.tv/2019/05/22/suriyelilerin-kaldigi-cadir-kentlerkapatiliyorgelecekleri-belirsiz/.

Green, Molly. "Language barriers and health of Syrian refugees in Germany." American journal of public health 107, sy 4 (2017): 486-499.

Gürer, Ömer Fethi. "36 bin 385 Suriyeli imam hatip okullarında eğitim görüyor”. BirGün Gazetesi. Erişim: 16 Nisan 2019. https://www.birgun.net/haber-detay/36-bin-385-suriyeli-imam-hatipokullarinda-egitimgoruyor-209499.html.

Ihlamur-Öner, Suna Gülfer. “Türkiye'nin Suriyeli mültecilere yönelik politikası.” Ortadoğu Analiz 6, sy 61 (2014): 42-45.

Kap, Derya. "Suriyeli mülteciler: Türkiye'nin müstakbel vatandaşları.” Akademik Perspektif 1, sy 3 (2014): 30-35.

Kartal, Bilhan. “Türkiye’ye yönelik Suriyeli göçünün çok yönlü doğasına giriş”. İçinde Beklenmeyen misafirler: Suriyeli sı̆̆ınmacılar penceresinden Türkiye toplumunun geleceği, 13-29. Transnational Press London, 2018. 
Kızıl, Ömür, ve Cengiz Dönmez. "Türkiye'deki Suriyeli sığınmacılara sağlanan eğitim hizmetleri ve sosyal bilgiler eğitimi bağlamında bazı sorunların değerlendirilmesi." International Journal of Education Technology and Scientific Researches 2, sy 4 (2017): 207-239.

Kızılabdullah, Yıldız, ve Tuğrul Yürük. "Din eğitimi modelleri çerçevesinde Türkiye'deki din eğitimi üzerine genel bir değerlendirme.” Dini Araştırmalar 11, sy 32 (2008): 107-130.

Kolukırık, Suat. "Uluslararası göç ve Türkiye: Yerel uygulamalar ve görünümler." Zeitschrift fürdie Welt der Türken/Journal of World of Turks 6, sy 2 (2014): 37-53.

Landis, Joshua. "Islamic education in Syria: Undoing secularism". Teaching Islam: Textbooks and Religion in the Middle East, 2003, 177-196.

Miles, Matthew B., ve A. Michael Huberman. Qualitative data analysis: An expanded sourcebook. New York: Sage Publications, Inc, 1994.

Moralı, Gürkan. "Suriyeli mülteci çocuklara Türkçenin yabancı dil olarak öğretiminde karşılaşılan sorunlar." Uluslararası Toplum Araştırmaları Dergisi 8, sy 15 (2018): 1426-1449.

Özdemir, Ahmet Selman. “Türkçe eğitim merkezi - Mülteciler derneği”. Erişim 17 Haziran 2019. https://multeciler.org.tr/turkce-egitim-merkezi/.

Seydi, Ali Rıza. “Türkiye'nin Suriyeli sığınmacıların eğitim sorununun çözümüne yönelik izlediği politikalar." Süleyman Demirel Üniversitesi Fen-Edebiyat Fakültesi Sosyal Bilimler Dergisi 2014, sy 31 (2014): 267-305.

Sirkeci, Ibrahim. "Turkey's refugees, Syrians and refugees from Turkey: a country of insecurity." Migration Letters 14, sy 1 (2017): 127-144.

Şeker, Betul Dilara, Ibrahim Sirkeci, ve M. Murat Yüceşahin. Göç ve uyum. London: Transnational Press, 2015.

Tanrıkulu, Faik. “Türkiye'de yaşayan Suriyeli çocukların eğitim sorunu ve çözüm önerileri.” Liberal Düşünce Dergisi 22, sy 86 (2017): 127-144.

Taşpınar, Mehmet. Kuramdan uygulamaya öğretim ilke ve yöntemleri. Ankara: Pegem A Yayıncılık, 2017.

Tosun, Aybiçe, Ayşe Yorulmaz, İshak Tekin, ve Kübra Yildiz. "Mülteci öğrencilerin eğitim sorunları, eğitim ve din eğitiminden beklentileri: Eskişehir örneği.” Eskişehir Osmangazi Üniversitesi Sosyal Bilimler Dergisi 19, sy 1 (2018): 107-133.

Tosun, Cemal. Din ve kimlik. C. 118. Türkiye Diyanet Vakf1, 1993.

“Türkiye'deki Suriyeli Sayısı Nisan 2019 - mülteciler Derneği”. Erişim 29 Nisan 2019. https:// multeciler.org.tr/turkiyedeki-suriyeli-sayisi/.

Yavuz, Ömer, ve Sefa Mızrak. "Acil durumlarda okul çağındaki çocukların eğitimi: Türkiye'deki Suriyeli mülteciler örneği.” Göç Dergisi 3, sy 2 (2016): 175-199.

Yıldız, Özkan. "Türkiye kamplarında Suriyeli sığınmacılar: Sorunlar, Beklentiler, Türkiye ve Gelecek Algısı." Sosyoloji Araştırmaları Dergisi 16, sy 1 (2013): 140-169. 
